\title{
Pengaruh Modal Kerja,Total Hutang,Tingkat Inflasi dan Penjualan Bersih Terhadap Laba Bersih
}

\author{
Nevin Wijaya ${ }^{1}$, Veronika $^{2}$, Silvia Kosasih ${ }^{3 *}$, Feby Natalia $^{4}$ \\ 1,2,3,4) Universitas Prima Indonesia \\ nevinwijaya@gmail.com, vrnika2701@gmail.com, silviakosasih766@gmail.com
}

febyyhuangg2512@gmail.com

*Corresponding Author

Submitted: January 8, 2021

Accepted: January 11, 2021

Published: February 11, 2021

\begin{abstract}
The purpose of this research is to examine and analyze the effect of working capital, total debt, inflation rate, and net sales on net income in retail trading companies listed on the Indonesia Stock Exchange 2015-2018 period. The research of this population was 27 retail trading companies listed on the IDX for the 2015-2018 period. With purposive sampling technique, the number of research samples that meet the criteria is 9 companies, while the research method is descriptive quantitative research. The data collection method uses secondary data from financial reports while the data analysis model is multiple regression. The results of the $F$ test research, namely working capital, total debt, inflation rate, and net sales have an effect on net income in retail trading companies listed on the Indonesia Stock Exchange in 2015-2018. Partially working capital has no effect on net income, partially total debt and inflation rate have a negative and significant effect on net income, while net sales have a positive and significant effect on net income. The coefficient of determination found $R 2$ value of 0.313 (31.3\%). The independent variable affects net income by $31.3 \%$ and the remaining $68.7 \%$ is affected by other variables. The conclusion from the results of this test is that of the 4 variables tested, there is 1 variable, namely working capital which does not affect net income.
\end{abstract}

Keywords: Net Profit, Working Capital, Net Sales, Total Debt and Inflation Rate

\section{PENDAHULUAN}

Perusahaan dalam mengelola aktivitas selalu dituntut untuk semakin kreatif oleh karena adanya persaingan usaha yang semakin kompetitif. Semua perusahaan mempunyai tujuan pokok guna mendapatkan keuntungan. Laba bersih yakni nilai akhir yang didapatkan melalui keuntungan operasional dijumlahkan pemasukan lain yang kemudian dikurangkan oleh biaya lainnya. Umumnya pengukuran laba bertujuan membentuk alat pengendali serta landasan untuk keputusan manajemen, investor, kreditor, serta pemegang saham secara periodik ataupun berkesinambungan.

Laba bersih sendiri bisa dipergunakan untuk indikator dalam pengukuran kinerja manjemen. Berdasarkan data sekunder yang diolah peneliti dari laporan keuangan perusahaan MKNT pada tahun 2015 sampai 2017, peneliti mengamati perusahaan MKNT yang menerus mendapati peningkatan sampai tahun 2017 memiliki laba bersih sebesar Rp 37.374.914. Namun, di tahun 2018 menurun sebesar Rp.1.426.326 yang disebabkan karna terjadinya penurunan pada penjualan bersih sebesar $25,03 \%$ serta ekspansi perusahaan yang membebani beban pokok penjualan.

Hal yang bisa perusahaan lakukan dalam menghasilkan laba yakni melalui peningkatan efisiensi modal kerja untuk memperoleh penjualan, supaya kinerjanya bisa berjalan dengan baik dan dapat meminimalkan hutang. Modal kerja merupakan investasi perusahaan sebagai contoh komponen penting yang dipergunakan untuk operasi perusahaan yang berbentuk surat berharga, uang tunai, serta piutang dagang yang diharapkan dengan waktu singkat melalui penjualan dapat masuk pada perusahaan. Dengan adanya modal kerja baik, kegiatan perusahaan akan menjadi lancar serta mendorong kesuksesan usaha dalam mencapai laba. 
Dana yang dibutuhkan perusahaan yang bertumbuh tentunya semakin besar, dimana dalam pemenuhan dana itu diperlukan sumber eksternal berupa hutang. Namun pada pemakaian hutang, dibutuhkan sikap hati-hati terkait risikonya. Adapun risiko tinggi berupa biaya modal, dikarenakan hal tersebut perusahaan harus memperhatikan keseimbangan dari modal eksternal serta modal sendiri ketika menentukan keputusan dalam mempergunakan hutang.

Inflasi yang tidak stabil mampu menimbulkan uncertainty ataupun ketidakpastian terhadap pelaku ekonomi ketika menentukan keputusan, maka dari itu tingkatan inflasi berpengaruh terhadap laba bersih perusahaan. Terdapat faktor-faktor lain sebagai penentu atas perolehan, laba yang optimal, salah satunya tingkat penjualan. Tujuan terakhir proses meningkatkan penjualan yang perusahaan lakukan di harapkan mampu berpengaruh ke terus meningkatnya laba bersih.

Penelitian ini merupakan kelanjutan dari penelitian (Zahara \& Zannati, 2018) yang menemukan total utang dan penjualan tidak berpengaruh terhadap laba bersih, sedangkan modal kerja berpengaruh positif terhadap laba bersih. Hasil lainnya oleh (Dini \& Nazahah, 2017) menunjukkan total utang dan modal kerja berpengaruh positif terhadap laba bersih. Penelitian ini menambahkan faktor eksternal yang mempengaruhi laba bersih yaitu tingkat inflasi.

Adapun penelitian ini penting dilakukan dikarena begitu pentingnya laba bersih pada suatu perusahaan melatarbelakangi peneliti untuk menganalisis faktor yang mempengaruhi laba bersih pada sektor perdagangan eceran yang diobservasi oleh peneliti dari 27 perusahaan yang terdaftar di BEI terdapat 12 perusahaan sektor ini mengalami kerugian, hal ini disebabkan melemahnya daya beli konsumen terhadap produk perdagangan karena adanya globalisasi yang memungkinkan konsumen mencari produk yang lebih murah.

\section{STUDI LITERATUR}

\section{Teori Pengaruh Modal Kerja Terhadap Laba Bersih}

Hasil penelitian (Rialdy, 2017) menunjukkan modal kerja berpengaruh secara signifikan positif terhadap laba usaha. Kondisi tersebut senada pada teori Kasmir (2015:256), yakni untuk perusahaan modal berfungsi memaksimalkan penggunaan aktiva lancar supaya mendorong laba serta penjualan.

Namun pada praktik di lapangan teori diatas tidak sesuai pada fakta, terlihat dalam sejumlah perusahaan perdagangan dimana meski modal kerja telah meningkat, laba bersih tetap tidak bisa meningkat. Ada sejumlah faktor yang menyebabkan tidak dapat meningkatkan laba, contohnya ekonomi global melemah yang berpengaruh pada perkembangan sektor perdagangan di Indonesia. Rumus yang dipergunakan dalam perhitungan modal kerja yakni:

$$
\text { Modal Kerja = Aktiva Lancar }- \text { Hutang Lancar }
$$

\section{Teori Pengaruh Total Hutang Terhadap Laba Bersih}

Hasil penelitian (Putri \& Supadmi, 2016) menjelaskan bahwasanya tingkat hutang berpengaruh negatif terhadap persistensi laba. Sesuai dengan teori (Narafin, 2013), dimana keterkaitan total hutang terhadap laba bersih yakni penambahan hutang rentang panjang serta pendek dalam ekspansi aktivitas perusahaan, pemasaran, serta produksi yang bertujuan menghasilkan laba setinggi-tingginya. Dengan meningkatnya aktivitas perluasan tersebut selaku akibat meningkatnya pembelanjaan mempergunakan hutang mampu meningkatkan laba. Rumus yang dipergunakan dalam perhitungan total hutang yakni:

$$
\text { Total Hutang = Hutang Jangka Panjang + Hutang Jangka Pendek }
$$

\section{Teori Pengaruh Tingkat Inflasi Terhadap Laba Bersih}

Hasil penelitian (Gustiono, 2017) menjelaskan bahwasanya tingkat inflasi berpengaruh negatif signifikan terhadap profitabilitas (ROA). Inflasi adalah suatu kejadian dimana berbagai harga meningkat dengan berkelanjutan, naiknya harga barang dimana hanya satu ataupun dua saja tidak bisa dinyatakan inflasi, dengan pengecualian apabila peningkatan harga tersebut menjadi luas ataupun menyebabkan harga barang lain ikut meningkat juga (Bank Indonesia,2016).

Tingkat inflasi dalam perekonomian di satu sisi selalu relative menimbulkan rasa takut 
dikarenakan bias membuat daya beli melemah, juga bisa memulihkan kapabilitas produksi yang arahnya menuju kritis konsumsi serta produksi. Tetapi dari sudut pandang lainnya,tidak adanya inflasi mengindikasikan ketiadaan pergerakan positif pada perekonomian dikarenakan tidak berubahnya harga yang malah bias membuat sektor industri melemah.

\section{Teori Pengaruh Total Penjualan Terhadap Laba Bersih}

Hasil penelitian menjelaskan bahwasanya total penjualan dengan signifikan mempengaruhi laba bersih dalam perusahaan sektor perdagangan yang terdaftar di BEI. Senada pada opini (Raharjo, 2016), terdapatnya kaitan yang kuat terkait penjualan pada meningkatnya laba bersih suatu perusahaan dimana keadaan tersebut bisa di lihat pada laporan laba rugi, sebab laba muncul apabila penjualan produk lebih tinggi di bandingkan berbagai biaya yang di keluarkan.

Namun pada peraktik dilapangan teori diatas tidak sejalan dengan fakta yang ada, dimana penjualan secara menerusmeningkat namun tidak disertai oleh meningkatnya laba bersih. Hal ini disebabkan perusahaan tidak dapat mengontrol naiknya beban penjualan dan administrasi umum. Rumus yang dipergunakan dalam perhitungan penjualan bersih yakni:

Penjualan Bersih $=$ Penjualan $-($ Retur Penjualan + Potongan Penjualan $)$

\section{Kerangka Konseptual}

Modal kerja yakni suatu modal yang semestinya terdapat pada perusahaan supaya perusahaan bisa beroperasi dengan semakin lancar dan supaya tercapai tujuan terakhir perusahaan dalam memperoleh laba. Jika kekurangan modal kerja hal tersebut bisa menyebabkan perusahaan kehilangan keuntungan.

Total hutang yang dimiliki suatu perusahaan juga mempengaruhi meningkat dan menurunnya laba. Penggunaan hutang yang semakin besar membuat kewajiban menjadi besar juga, melalui harapan penggunaan hutang, di periode selanjutnya mampu memproduksi lebih banyak laba.

Inflasi yakni peningkatan secara umum harga jasa maupun barang dengan menerus yang merupakan keperluan pokok masyarakat ataupun menurunnya daya jual mata uang.

Kegiatan penjualan untuk perusahaan adalah hal primer serta memiliki arti keuntungan terpenting apabila dibanding pada kegiatan lainnya pada aktivitas operasional perusahaan tersebut, kegiatan ini di tujukan guna menarik konsumen serta memberikan arahan supaya konsumen bias melakukan penyesuaian terhadap apa yang ia butuhkan pada produk yang di tawarkan oleh perusahaan.

Hubungan diantara variabel bebas pada variabel terikat berdasar pada uraian sejumlah teori yang sudah dijelaskan terkait modal kerja, total hutang, tingkat inflasi dan penjualan terhadap laba bersih maka bisa disimpulkan dalam kerangka konseptual meliputi:

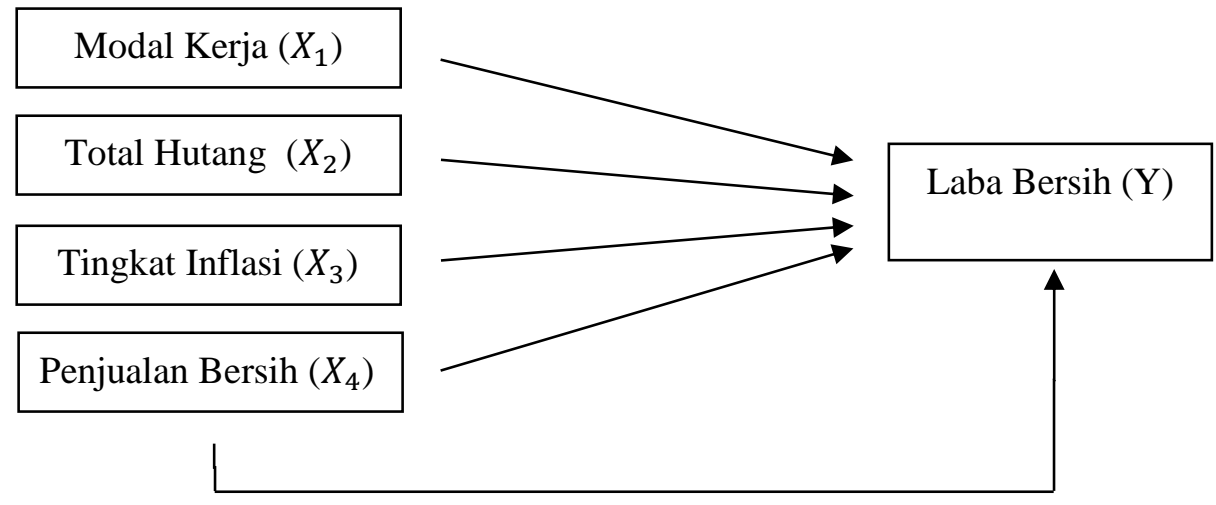

Gambar 1 Kerangka Konseptual Penelitian

\section{Hipotesis Penelitian}

Hipotesis yakni tanggapan temporer terkait pertanyaan pada penelitian. Adapun peneliti mengajukan hipotesis meliputi: 
$\mathrm{H}_{1}$ : Ada pengaruh Modal Kerja pada Laba Bersih dalam Perusahan Perdagangan Eceran yang terdaftar di BEI periode 2015-2018

$\mathrm{H}_{2}$ : Ada pengaruh Total Hutang pada Laba Bersih dalamPerusahan Perdagangan Eceran yang terdaftar di BEI periode 2015-2018

$\mathrm{H}_{3}$ : Ada pengaruh Total Tingkat Inflasi pada Laba Bersih dalamPerusahan Perdagangan Eceran yang terdaftar di BEI periode 2015-2018

$\mathrm{H}_{4}$ : Ada pengaruh Total Penjualan Bersih pada Laba Bersih dalamPerusahan Perdagangan Eceran yang terdaftar di BEI periode 2015-2018.

$\mathrm{H}_{5}$ : Ada pengaruh Modal Kerja, Total Hutang, Tingkat Inflasi dan Penjualan Bersih terhadap Laba Bersih dalam Perusahan Perdagangan Eceran yang terdaftar di BEI periode 20152018.

\section{Pendekatan Penelitian}

\section{METODE}

Pendekatan penelitian mempergunakan penelitian Kuantitatif, karena penelitian ini menggunakan data statistik berupa angka-angka yang didapatkan dari data sekunder laporan keuangan. Jenis penelitian mempergunakan penelitian deskriptif, teori yang digunakan oleh Sugiyono (2017:29).

Sifat penelitian menggunakan penelitian Eksplanatori, teori yang digunakan menurut (Sugiyono, 2017).

\section{Populasi dan sampel Penelitian}

Tiap anggota populasi bisa diteliti dalam melihat sifat populasi tersebut, dipergunakan populasi 27 perusahaan Sektor Perdagangan Eceran Periode 2015-2018.

Pemilihan sampel mempergunakan metode purposive sampling, Sampel yang dipergunakan yakni Perusahaan Sektor Perdagangan Eceran yang terdaftar di BEI tahun 2015-2018

Kriteria-kriteria yang dipergunakan meliputi:

1. Perusahaan sektor Perdagangan Eceran yang terdaftar di BEI tahun 2015-2018.

2. Perusahaan Sektor Perdagangan Eceran yang tidak melaksanakan publikasi laporan keuangan dengan lengkap secara berturut-berturut dalam tahun 2015-2018.

3. Perusahaan Sektor Perdagangan Eceran yang mempunyai laba negative dalam periode 2015-2018.

Tabel 2. Tabel Pemilihan Sampel.

\begin{tabular}{|l|l|l|}
\hline No & Keterangan & Jumlah \\
\hline 1. & Perusahaan perdagangan eceran yang terdaftar di BEI & 27 \\
\hline 2. & $\begin{array}{l}\text { Perusahaan perdagangan eceran yang tidak melaksanakan publikasi laporan } \\
\text { keuangan dan tidak memiliki data lengkap dalam tahun 2015-2018 }\end{array}$ & $(6)$ \\
\hline 3. & $\begin{array}{l}\text { Perusahaan perdagangan eceran yang tidak mendapatkan laba bersih positif } \\
\text { dalam tahun 2015-2018 berturut-turut }\end{array}$ & $(12)$ \\
\hline & Jumlah Sampel & 9 \\
\hline & Jumlah Periode & 4 \\
\hline & Jumlah Observasi $=19 \times 4$ & 36 \\
\hline
\end{tabular}

\section{Teknik Pengumpulan Data}

Dokumentasi merupakan teknik dalam mengumpulkan data yang dipergunakan pada penelitian ini, teori yang digunakan menurut Sugiyono (2017:240) dokumen yakni rekaman data fenomena yang sudah lampau. Data yang dipergunakan yakni Laporan Keuangan yang berasal dari Perusahaan Sektor Perdanganan Eceran yang terdaftar di BEI tahun 2015-2018.

Skala pengukuran pada variabel modal kerja, hutang, penjualan dan laba bersih menggunakan skala nominal dalam satuan rupiah sedangkan tingkat inflasi menggunakan skala rasio dalam satuan persen. Modal kerja dihitung dengan mencari selisih aktiva lancar dan hutang lancar, hutang yang digunakan adalah total hutang yang dilihat pada laporan neraca, sedangkan nilai penjualan dan laba bersih yang digunakan adalah total penjualan bersih dan laba bersih setelah pajak yang dilihat pada 
laporan rugi laba. Untuk mendapatkan data inflasi pada penelitian ini diunduh dari website www.bi.go.id dengan menggunakan data periode Desember 2015-2018.

\section{Jenis dan Sumber Data}

Peneliti mempergunakan data sekunder teori yang dipergunakan Menurut Sugiono (2017:137).

\section{Uji Asumsi Klasik}

Uji Normalitas

Duwi Priyatno (2013:39) menjelaskan, uji normalitas tujuannya yakni melaksanakan pengukuran terkait normal ataukah tidaknya data dalam variabel berdistribusi.Model regresi yang baik yakni mempunyai nilai residual yang terdistribusi normal.

\section{Uji Multikolinieritas}

Duwi Priyatno (2013:48) menjelaskan, multikolinieritas yakni kondisipada metode regresi dimana berlangsung hubungan yang hampir sempurna ataupun bahkan sempurna antar variable independen. Tidak terdapatnya multikolinearitas merupakan prasyarat yang perlu dipenuhi pada model regresi. Uji yang dilaksanakan dalam melihat terdapat ataupun tidaknya gejala multikolinearitas yakni melalui memeriksa nilai VIF serta Tolerance. Apabilanilai VIF dibawah 10,00 serta nilai Tolerance melebihi 0,100 .

\section{Uji Autokorelasi}

Ghozali (2016:108) menjelaskan, uji autokorelasi dilaksanakan guna melaksanakan uji terkait adanya kesalahan penggangu pada model regresi terhadap periode $\mathrm{t}$ dengan kesalahan pengganggu dalam periode t-1 (sebelum), dimana yang baik yakni regresi yang terbebas oleh autokorelasi. Pendeteksian terdapatnya autokorelasi pada penelitian ini melalui uji Run Test.

\section{Uji Heteroskedastisitas}

Uji ini tujuannya yakni mengetahuiada tidaknya ketidak sesuaian varians pada residual pengamatan satu terhadap pengamatan lainnya. Regresi yang sesuai syarat yakni ada kesesuaian varians dari residual pengamatan satu terhadap pengamatan yang lain sama ataupun dianggap homoskedastisitas, dimana yang dipergunakan meliputi:

1. Memeriksa grafik plot diantara nilai prediksi variable dependen ataupun terikat yakni ZPRED dengan residual DRESID.

2. Pengujian park mengusulkan guna meregres nilai LnU2i selaku variable dependen.

\section{Model Analisi Data Penelitian}

Model analsisis data ini menggunakan analisis regresi berganda dalam mengecek pengaruh variabel independen (bebas) serta variabel dependen (terikat). Analisis data dalam pengelolaan data mempergunakan SPSS. Adapun rumus analisis regresi linier berganda meliputi:

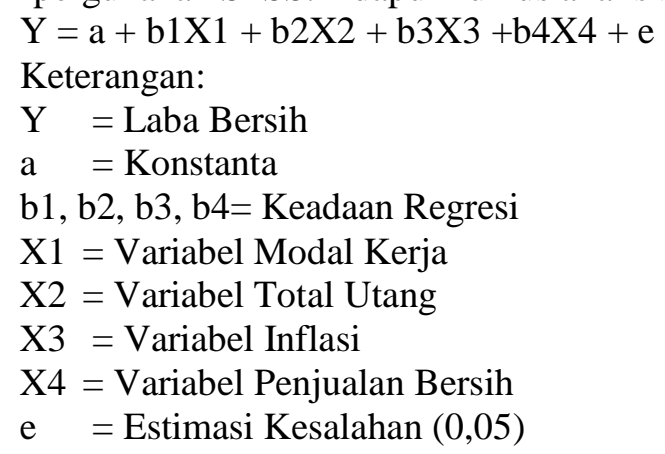

\section{Uji Koefisien Determinasi $\left(\mathbf{R}^{2}\right)$}

Ghozali (2016: 97) menjelaskan, $\mathrm{R}^{2}$ ditunjukkan dalam menilai jauhnya kapabilitas model untuk menjabarkan variasi terikat. Apabila $\mathrm{R}^{2}$ semakin tinggi ataupun dekat dengan 1 , artinya kapabilitas variabel bebas $(\mathrm{X})$ yakni besar pada variabel terikat $(\mathrm{Y})$. 


\section{Uji Koefisien Secara Simultan(Uji-F)}

Ghozali (2016: 98)menuturkan, uji statistik F menyampaikan apa seluruh semua variabel yang masuk pada model ataupun variabel bebas berpengaruh dengan bersamaan pada variabel terikat. Berikut cara pengujiannya:

Dipergunakan statistik $\mathrm{F}$ melalui kriteria penentuan keputusan melalui perbandingan nilai $\mathrm{F}$ hasil perhitungan pada nilai $\mathrm{F}$ tabel, yaitu:

H_a ditolak ataupun H_o diterima apabila nilai sig $>0,05$ serta $F_{\text {hitung }} \leq \mathrm{F}_{\text {tabel }}$

H_o ditolak ataupun $\mathrm{H} \_$a diterima apabila nilai sig $<0,05$ serta $\mathrm{F}_{\text {hitung }}>\mathrm{F}_{\text {tabel }}$

\section{Uji Signifikan Parsial (Uji-t)}

Ghozali (2016: 98-99) menjelaskan, uji Statistik t memperlihatkan sejauh apa pengaruh variabel bebas/penjelas dengan individual untuk menjabarkan variasi variabel terikat.

Pelaksanaan uji t yakni melalui memperbandingkan nilai statistik t pada titik kritis dalam tabel. Bila nilai statistik t perhitungan melebihi nilai t tabel, artinya variabel bebas dengan individual berpengaruh pada variabel terikat, dengan kriteria meliputi:

H_(a )ditolak ataupun $H_{-}$(o ) diterima apabila nilai sig $>0,05$ serta $t_{\text {hitung }} \leq t_{\text {tabel }}$

H_(0 )ditolak ataupun H_(a )diterima apabila nilai sig $<0,05$ serta $t_{\text {hitung }}<t_{\text {tabel }}$

\section{Hasil Penelitian dan Deskripsi Data}

\section{HASIL}

Pelaksanaan penelitian terhadap 9 Perusahaan Perdagangan Eceran yang terdaftar di BEI dengan 36 data. Pendeskripsian data penelitian ini untuk menjabarkan keseluruhan sampel diteliti, nilai minimumnya, nilai maximum, meannya dan standar deviasinya.

Tabel 3. Statistik Deskriptif

\begin{tabular}{|l|r|r|r|r|r|}
\hline \multicolumn{7}{|c|}{ Descriptive Statistics } \\
\hline & $\mathrm{N}$ & \multicolumn{1}{|c|}{ Minimum } & \multicolumn{1}{c|}{ Maximum } & \multicolumn{1}{c|}{ Mean } & \multicolumn{1}{c|}{ Std. Deviation } \\
\hline $\begin{array}{l}\text { Modal } \\
\text { Kerja }\end{array}$ & 36 & -1511713000000.00 & 6224911000000.00 & 1609084889797.4165 & 1953685308004.16430 \\
\hline Hutang & 36 & 638724157543.00 & 16651570000000.00 & 4809195443489.7230 & 4003418931160.44240 \\
\hline Inflasi & 36 & 3.20 & 6.38 & 4.2300 & 1.27781 \\
\hline Penjualan & 36 & 4742525934225.00 & 66817305000000.00 & 18263038297413.0000 & 16472634583350.79500 \\
\hline Laba Bersih & 36 & 30095070000.00 & 2019705000000.00 & 535077583207.6668 & 499206903831.04895 \\
\hline $\begin{array}{l}\text { Valid } \\
\text { N(listwise) }\end{array}$ & 36 & \multicolumn{7}{|c|}{} \\
\hline
\end{tabular}

Sumber : olahan data

Adapun uraian Tabel 3 yakni:

1. Nilai minimum modal kerja $-1.511 .713 .000 .000,00$, nilai maximum 6.224.911.000.000,00, meannya 1.609.084.889.797,4165 dan std.deviasi 1.953.685.308.004,16430.

2. Nilai minimum total hutang 638.724.157.543,00, nilai maximum 16.651.570.000.000,00, meannya 4.809.195.443.489,7230 dan std.deviasi 4.003.418.931.160,44240.

3. Nilai minimum inflasi 3,20, nilai maximum 6,38, meannya 4,2300 dan std.deviasi 1,2778 .

4. Nilai minimum penjualan 4.742.525.934.225,00, nilai maximum 66.817.305.000.000,00, meannya 18.263.038.297.413,0000 dan std.deviasi 16.472.634.583.350,79500.

5. Nilai minimum laba bersih 30.095.070.000,00, nilai maximum 2.019.705.000.000,00, meannya 535.077.583.207,6668 dan std.deviasi 499.206.903.831,04895.

\section{Uji Asumsi Klasik}

\section{Uji Normalitas}

Normalitas pengujian ini untuk membuktikan normalnya ataupun tidaknya data penelitian ini.

Adapun normalitas statistik dengan pengukuran one-samplekolmogorov smirnov dengan sig. di atas 0,05 berarti normal. Pengujian yakni : 
Owner: Riset \& Jurnal Akuntansi

e-ISSN : 2548-9224|p-ISSN : 2548-7507

Volume 5 Nomor 1, Februari 2021

DOI : https://doi.org/10.33395/owner.v5i1.366

Tabel 4.One-Sample Kolmogorov Smirnov Sebelum Transformasi

\begin{tabular}{|l|l|r|}
\hline \multicolumn{2}{|l|}{} & Unstandardized Residual \\
\hline \multirow{2}{*}{ Normal Parameters } & 36 \\
\hline \multirow{2}{*}{$\begin{array}{l}\text { Most Extreme } \\
\text { Differences }\end{array}$} & Mean & -.0000271 \\
\cline { 2 - 3 } & Std. Deviation & 480695439228.16310000 \\
\hline \multicolumn{2}{|l|}{ Test Statistic } & .186 \\
\cline { 2 - 3 } Asymp. Sig. (2-tailed) & Positive & .186 \\
\cline { 2 - 3 } & Negative & .132 \\
\hline \multicolumn{2}{|l|}{ a. Test distribution is Normal. } \\
\hline \multicolumn{2}{|l|}{ b. Calculated from data. } \\
\hline \multicolumn{2}{|l|}{ c. Lilliefors Significance Correction. } \\
\hline
\end{tabular}

Asymp signifikannya bernilai 0,003 ada dibawahnya 0,05 membuktikan data tidak normal. Ketidaknormalan data penelitian ini dapat diobati dengan tranformasi ln.

Tabel 5. One-Sample Kolmogorov Smirnov Sesudah Transformasi

\begin{tabular}{|l|l|r|}
\hline \multicolumn{2}{|l|}{} & Unstandardized Residual \\
\hline N & 29 \\
\hline \multirow{2}{*}{ Normal Parameters ${ }^{\mathrm{a}, \mathrm{b}}$} & Mean & .0000000 \\
\cline { 2 - 3 } & Std. Deviation & .78376111 \\
\hline & Absolute & .091 \\
\cline { 2 - 3 } & Positive & .079 \\
\cline { 2 - 3 } & Negative & -.091 \\
\hline \multicolumn{2}{|l|}{ Test Statistic } & .091 \\
\hline Asymp. Sig. (2-tailed) & $.200^{\mathrm{c}, \mathrm{d}}$ \\
\hline a. Test distribution is Normal. \\
\hline \multicolumn{2}{|l|}{ b. Calculated from data. } \\
\hline \multicolumn{2}{|l|}{ c. Lilliefors Significance Correction. } \\
\hline d. This is a lower bound of the true significance. \\
\hline
\end{tabular}

Asymp signifikannya bernilai 0,200 berada diatas 0,05 membuktikan data normal.

\section{Uji Multikolinearitas}

Multikolinearitas diuji masih terdapatkah korelasi pada variabel independennya. Kriterianya VIF $<10$ dan tolerance $>0,1$.

Tabel 6. Hasil Uji Multikolinearitas Sesudah Transformasi

\begin{tabular}{|c|c|c|c|}
\hline \multirow{2}{*}{\multicolumn{2}{|c|}{ Model }} & \multicolumn{2}{|c|}{ Collinearity Statistics } \\
\hline & & Tolerance & VIF \\
\hline \multirow[t]{5}{*}{1} & (Constant) & & \\
\hline & Ln_ModalKerja & .723 & 1.383 \\
\hline & Ln_Hutang & .160 & 6.265 \\
\hline & Ln_Inflasi & .985 & 1.015 \\
\hline & Ln_Penjualan & .153 & 6.519 \\
\hline
\end{tabular}

Keseluruhan variabel independennya pada uji sebelum dan sesudah transformasi memenuhi kriteria VIF dan tolerance sehingga data tidak ada multikolinearitas.

\section{Uji Autokorelasi}

Autokorelasi diuji guna memperlihatkan terdapatkah kesalahan korelasi pengganggu periode $\mathrm{t}$ pada periode sebelumnya. Kriterianya durbin Watson. 
Owner: Riset \& Jurnal Akuntansi

e-ISSN : 2548-9224 |p-ISSN : 2548-7507

Volume 5 Nomor 1, Februari 2021

DOI : https://doi.org/10.33395/owner.v5i1.366

Tabel 7. Uji Run Test

\begin{tabular}{|l|r|}
\hline \multicolumn{2}{|c|}{ Runs Test } \\
\hline & Unstandardized Residual \\
\hline Test Value & .07851 \\
\hline Cases $<$ Test Value & 14 \\
\hline Cases $>=$ Test Value & 15 \\
\hline Total Cases & 29 \\
\hline Number of Runs & 14 \\
\hline Z & -.372 \\
\hline Asymp. Sig. (2-tailed) & .710 \\
\hline a. Median & \\
\hline
\end{tabular}

Asymp signifikannya 0,710 melebihi 0,05 tidak berlangsung autokorelasi.

\section{Uji Heteroskedastisitas}

Heterokedastisitas diuji untuk mengetahui adanya ataupun tidaknya persamaan varian dalam satu pengamatan terhadap pengamatan lainnya. Heteroskedastisitas dengan scatterplot grafiknya:

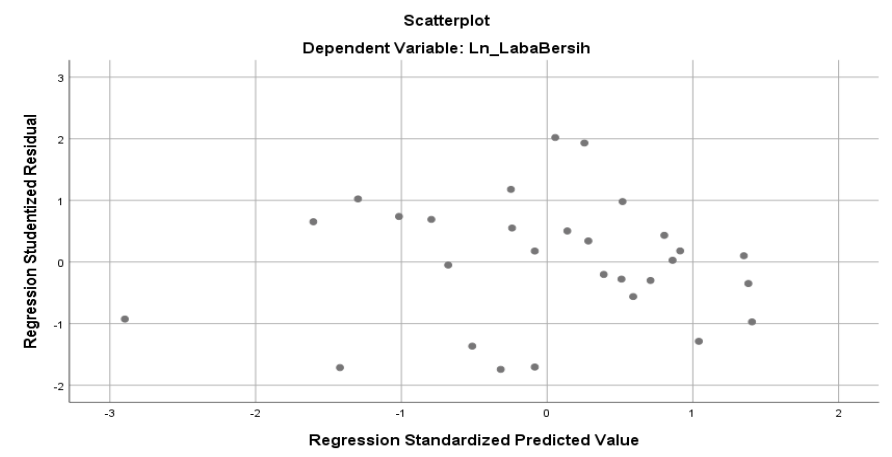

Gambar 2. Scatterplot Sesudah Transformasi

Berdasarkan Gambar 2. terlihat titik menyebar dengan mengacak serta tidak menyusun pola sehingga tidak mengandung heteroskedastisitas.

Tabel 8. Uji Park

\begin{tabular}{|c|c|c|c|c|c|c|}
\hline \multicolumn{7}{|c|}{ Coefficients $^{\mathrm{a}}$} \\
\hline \multirow{2}{*}{\multicolumn{2}{|c|}{ Model }} & \multicolumn{2}{|c|}{ Unstandardized Coefficients } & \multirow{2}{*}{$\begin{array}{c}\begin{array}{c}\text { Standardized } \\
\text { Coefficients }\end{array} \\
\text { Beta }\end{array}$} & \multirow[b]{2}{*}{$\mathrm{t}$} & \multirow[b]{2}{*}{ Sig. } \\
\hline & & $\mathrm{B}$ & Std. Error & & & \\
\hline \multirow[t]{5}{*}{1} & (Constant) & 30.032 & 18.368 & & 1.635 & .115 \\
\hline & Ln_ModalKerja & -.602 & .481 & -.255 & -1.253 & .222 \\
\hline & Ln_Hutang & 1.898 & 1.143 & .719 & 1.661 & .110 \\
\hline & Ln_Inflasi & -.263 & 1.405 & -.033 & -.187 & .853 \\
\hline & Ln Penjualan & -2.294 & 1.314 & -.770 & -1.745 & .094 \\
\hline
\end{tabular}

Berdasarkan Tabel 8 terlihat keseluruhan variabel bebas yang nilai signifikan melebihi 0,05 tidak terjadi heteroskedastisitas.

\section{Hasil Analisis Data}

Analisis Regresi Linier Berganda

Analisis regresi linear berganda membuktikan ada hubungan diantara variabel bebas independen serta variabel terikat. Persamaannya yakni : 
Ln_Laba Bersih $=29,380$ - 0,214 Ln_Modal Kerja - 1,555 Ln_Hutang - 1,528 Ln_Inflasi + 1,663 Ln_Penjualan

1. Nilai a sebesar 29,380 berarti variabel independen dianggap nol dengan laba bersih 29,380.

2. Nilai koefisien modal kerja $-0,214$ atau $-21,4 \%$ berarti tiap peningkatan modal kerja satu persen maka laba bersih mengalami penurunan $21,4 \%$.

3. Nilai koefisien total hutang $-1,555$ atau $-155,5 \%$ berarti tiap peningkatan total hutang satu persen maka laba bersih mengalami penurunan $155,5 \%$.

4. Nilai koefisien inflasi $-1,528$ atau $-152,8 \%$ berarti setiap meningkatnya inflasi satu persen artinya laba bersih mendapati penurunan $152,8 \%$.

5. Nilai koefisien penjualan 1,663 atau $166,3 \%$ berarti tiap peningkatan penjualan satu persen maka laba bersih mengalami peningkatan $166,3 \%$.

\section{Koefisien Determinasi $\left(\mathbf{R}^{2}\right)$}

$\mathrm{R}^{2}$ membuktikan seberapakah besar pengaruh variabel independennya pada dependen. Pengujiannya yakni :

Tabel 9. Koefisien Determinasi $\left(\mathrm{R}^{2}\right)$

\begin{tabular}{|l|c|r|r|c|}
\hline \multicolumn{5}{|c|}{ Model Summary $^{\mathbf{b}}$} \\
\hline Model & R & R Square & Adjusted R Square & Std. Error of the Estimate \\
\hline 1 & $.641^{\mathrm{a}}$ & .411 & .313 & .84656 \\
\hline a. Predictors: (Constant), Ln_Penjualan, Ln_Inflasi, Ln_ModalKerja, Ln_Hutang \\
\hline \multicolumn{2}{|l}{ b. Dependent Variable: Ln_LabaBersih } \\
\hline
\end{tabular}

Berdasar pada Tabel 9 nilai adjusted $R$ Square (R2) 0,313 (31,3\%). variabel independen berpengaruh padalaba bersihsejumlah $31,3 \%$ serta $68,7 \%$ sisanya terpengaruh variabel lainnya.

\section{Pengujian Hipotesis Secara Simultan (Uji Statistik F)}

Hasil pengujiannya dijabarkan, meliputi:

Tabel 10. Uji Statistik F

\begin{tabular}{|l|l|r|r|r|r|c|}
\hline \multicolumn{7}{|l|}{ ANOVA $^{\mathrm{a}}$} \\
\hline \multirow{2}{*}{ Model } & $\begin{array}{c}\text { Sum of } \\
\text { Squares }\end{array}$ & df & Mean Square & F & Sig. \\
\hline \multirow{3}{*}{1} & Regression & 12.026 & 4 & 3.006 & 4.195 & $.010^{\mathrm{b}}$ \\
\cline { 2 - 7 } & Residual & 17.200 & 24 & .717 & & \\
\cline { 2 - 7 } & Total & 29.226 & 28 & & & \\
\hline \multicolumn{2}{|l}{ a. Dependent Variable: Ln_LabaBersih } \\
\hline
\end{tabular}

Melalui Tabel 10 terlihat $F_{\text {hitung }} 4,195$, nilai signifikan 0,010 dan $F_{\text {tabel }}(29-5=24)$ yakni sejumlah 2,78 didapati kesimpulan meliputi $F_{\text {hitung }}>F_{\text {tabel }}$ yakni 4,195> 2,78 dengan keputusan Ha diterima serta Ho ditolak, artinya modal kerja,total hutang,tingkat inflasi, serta penjualan bersih berpengaruh terhadap laba bersih dalam perusahaan perdagangan eceran yang terdaftar di BEI.

\section{Pengujian Hipotesis Secara Parsial (Uji Statistik t)}

Hasil pengujiannya dijabarkan, meliputi:

Tabel 11. Uji Statistik t

\begin{tabular}{|c|c|c|c|c|c|}
\hline \multicolumn{6}{|c|}{ Coefficients $^{\mathbf{a}}$} \\
\hline \multirow{2}{*}{\multicolumn{2}{|c|}{ Model }} & \multicolumn{2}{|c|}{ Unstandardized Coefficients } & \multirow[b]{2}{*}{$\mathrm{t}$} & \multirow[b]{2}{*}{ Sig. } \\
\hline & & $\mathrm{B}$ & Std. Error & & \\
\hline \multirow[t]{4}{*}{1} & (Constant) & 29.380 & 7.792 & 3.770 & .001 \\
\hline & Ln_ModalKerja & -.214 & .204 & -1.049 & .305 \\
\hline & Ln_Hutang & -1.555 & .485 & -3.209 & .004 \\
\hline & Ln_Inflasi & -1.528 & .596 & -2.563 & .017 \\
\hline
\end{tabular}




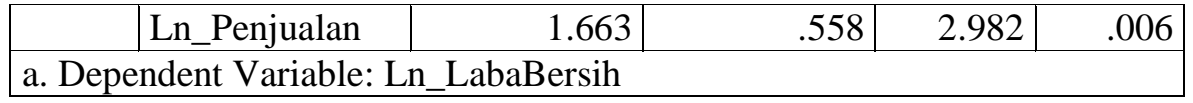

1. Modal kerja nilai thitung $-1,049$; nilai signifikan 0,305 sementara $t_{\text {tabel }}(29-4=25)$ sejumlah 2,059, - $t_{\text {hitung }}>-t_{\text {tabelyaitu }}-1,049>-2,059$ keputusannya Ho diterima serta Ha ditolak, yang berarti modal kerja tidak mempengaruhi laba bersih dalam perusahaan perdagangan eceran yang terdaftar di BEI.

2. Total hutang nilai thitung $-3,209$, nilai signifikan $0,004, t_{\text {tabel }}$ yakni sejumlah $2,059,--$ $t_{\text {hitung }}<-t_{\text {tabel }}$ yakni $-3,209<-2,059$ keputusannya Ha diterima serta Ho ditolak, artinya total hutang mempengaruhi laba bersih dalam perusahaan perdagangan eceran yang terdaftar di BEI.

3. Inflasi nilai thitung $-2,563$, signifikan 0,017 , - thitung $_{\text {- }}$ t tabelyakni $_{\text {ta }}-2,563<-2,059$ keputusannya Ha diterima dan Ho ditolak, artinya tingkat inflasi mempengaruhi laba bersih dalam perusahaan perdagangan eceran yang terdaftar di BEI.

4. Penjualan nilai thitung 2,982, nilai signifikan $0,006, t_{\text {hitung }}>t_{\text {tabel }}$ yaitu $2,982>2,059$ keputusannya Ha diterima dan Ho ditolak, artinya penjualan bersih mempengaruhi laba bersih dalam perusahaan perdagangan eceran yang terdaftar di BEI.

\section{Pengaruh Modal Kerja Terhadap Laba Bersih}

\section{PEMBAHASAN}

Hasilnya yakni modal kerja tidak mempengaruhi laba bersih dalam perusahaan perdagangan eceran yang terdaftar di BEI. Tidak sejalan dengan hasil yang diperoleh (Meiliana \& Nuryasman, 2020) yaitu modal kerja berpengaruh positif signifikan terhadap laba. Hasil itu tidak sejalan pada Kasmir (2015), yaitu modal kerja untuk perusahaan berfungsi mengoptimalkan penggunaan aktiva lancar untuk mendorong laba serta penjualan.

Adapun tidak berpengaruhnya modal kerja pada laba bersih pada sektor ini mengindikasikan adanya modal kerja yang berlebih menunjukkan perusahaan kurang produktif dalam menghasilkan penjualan untuk menciptakan labanya, yang dapat dilihat dari menumpuknya persediaan dan tingginya nilai piutang yang rata-rata melebihi umur piutangnya.

\section{Pengaruh Total Hutang Terhadap Laba Bersih}

Hasilnya yakni total hutang mempengaruhi laba bersih dalam perusahaan perdagangan eceran yang terdaftar di BEI. Namun penelitian (Handayani \& Mayasari, 2018) menemukan hutang tidak berpengaruh terhadap laba bersih. Hasil itu sejalan dengan M.Nafarin (2013), dimana keterkaitan total hutang terhadap laba bersih yakni melalui memperoleh hutang rentang panjang serta pendek guna ekspansi aktivitas perusahaan, pemasaran, serta produksi yang bertujuan mendapatkan laba setinggi-tingginya.

Hasil penelitian ini mengindikasikan, perusahaan perdagangan perlu mewaspadai penggunaan hutang yang tinggi dikarenakan melemahnya daya beli dapat mengakibatkan perusahaan kesulitan membayar hutang yang akhirnya perusahaan dapat semakin terbebani dengan adanya hutang yang semakin tinggi.

\section{Pengaruh Tingkat Inflasi Terhadap Laba Bersih}

Hasilnya yakni tingkat inflasi mempengaruhi laba bersih dalam perusahaan perdagangan eceran yang terdaftar di BEI. Namun penelitian (Daniel, Imanuel, \& Hanryono, 2016) menunjukkan inflasi tidak mempengaruhi pertumbuhan laba. Hasil itu sejalan dengan Bank Indonesia (2016) Inflasi adalah kejadian dimana berbagai harga meningkat dengan berkelanjutan, naiknya harga barang dimana hanya satu ataupun dua saja tidak bisa dinyatakan inflasi, dengan pengecualian apabila peningkatan harga tersebut menjadi luas ataupun menyebabkan harga barang lain ikut meningkat juga.

Hasil penelitian ini mengindikasikan bahwa inflasi mempengaruhi laba bersih sektor perdagangan, di mana terjadinya inflasi menyebabkan kenaikan harga barang-barang yang otomatis konsumen akan mengurangi pembelian, dengan demikian akan mempengaruhi penjualan dan 
akhirnya menurunnya laba bersih.

\section{Pengaruh Total Penjualan Terhadap Laba Bersih}

Hasilnya yakni penjualan bersih mempengaruhi laba bersih dalam perusahaan perdagangan eceran yang terdaftar di BEI. Sejalan dengan hasil penelitian (Susilawati \& Mulyana, 2018) yang menemukan adanya pengaruh positif signifikan penjualan terhadap laba bersih. Berbeda dengan hasil (Zahara \& Zannati, 2018) yang menemukan penjualan tidak berpengaruh terhadap laba bersih. Hasil itu sejalan dengan Budi Raharjo (2016), bahwasanya terdapatnya kaitan yang kuat terkait penjualan pada meningkatnya laba bersih suatu perusahaan dimana keadaan tersebut bisa di lihat pada laporan laba rugi, sebab laba muncul apabila penjualan produk lebih tinggi di bandingkan berbagai biaya yang di keluarkan.

Seperti diketahui pendapatan utama dari sektor ini adalah berasal dari penjualan barang dagangan, sehingga jika perusahaan mampu meningkatkan penjualannya dan menekan biaya operasionalnya maka dipastikan perusahaan akan memperoleh laba yang diharapkan.

\section{KESIMPULAN}

Sesuai akan hasil penelitian, di dapati kesimpulan secara parsial modal kerja tidak mempunyai pengaruh pada laba bersih dalam perusahaan perdagangan eceran yang terdaftar di BEI, total hutang dan tingkat inflasi mempunyai pengaruh signifikan serta negatif pada laba bersih dalam perusahaan perdagangan eceran yang terdaftar di BEI dan penjualan bersih mempunyai pengaruh signifikan serta positif pada laba bersih dalam perusahaan perdagangan eceran yang terdaftar di BEI. Secara simultan modal kerja, total hutang, tingkat inflasi, serta penjualan bersih berpengaruh pada laba bersih dalam perusahaan perdagangan eceran yang terdaftar di BEI.

\section{SARAN}

Adapun beberapa saran yang bisa penulis sampaikan meliputi:

1. Bagi perusahaan, jika terdapat perusahaan yang masih belum melaksanakan strategi serta laba bersihnya menurun, supaya dilaksanakan pengkajian lebih mendalam terkait faktor yang bisa berpengaruh pada laba bersih, contohnya volume penjualan serta biaya operasional.

2. Bagi Investor, hasil dari penelitian ini bisa berperan selaku bahan dalam mempertimbangkan langkah sebelum melaksanakan investasi dalam perusahaan tersebut.

3. Bagi peneliti selanjutnya, penulis menyarankan mengganti perusahaan sektor lainnya, menambahkan variabel bebas lainnya yang mempunyai pengaruh pada laba bersih.

4. Bagi Universitas Prima Indonesia, hasil dari penelitian ini bisa memberikan kontribusi karya ilmiah yang ada dalam perpustakaan, khususnya terkait berbagai faktor yang berpengaruh pada laba bersih.

\section{REFERENSI}

Daniel Hanryono2016Analisis Pengaruh Kinerja Keuangan Bank, Tingkat Inflasi dan BI Rate Terhadap Pertumbuhan LabaJournal of Accounting anf Business Studies Vol 1 No 1

Dini, \& Nazahah, K. (2017). Pengaruh Total dan Modal Kerja Terhadap Laba bersih (Survei Pada Perusahaan Sektor Pertambangan Yang Terdaftar di BEI Periode 2010-2015). JBPT UNIKOMP .

Ghozali, \& Imam. (2016). Aplikasi Analisis Multivariate Dengan Program SPSS. Semarang: Badan Penerbit Universitas Diponegoro.

Gustiono, R. (2017). Pengaruh Variabel Moneter (Inflasi, Suku Bunga dan Nilai Tukar) terhadap Profitabilitas Bank Pembangunan Daerah Sebelum dan Setelah Otonomi Daerah. Jurnal Ilmiah Universitas Brawijaya .

Handayani, V., \& Mayasari. (2018). Analisis Pengaruh Hutang Terhadap Laba Bersih Pada PT.Kereta Api Indonesia (Persero). JRAB: Jurnal Riset Akuntansi \& Bisnis , 18(1).

Hery. (2015). Analisis Laporan keuangan Pendekatan Rasio Keuangan. Yogyakarta: CAPS.

Hery. (2017). Kajian Riset Akuntansi Mengulas Berbagai Hasil Penelitian Terkini dalam Bidang Akuntansi dan Keuangan. Jakarta: PT Grasindo. 
Irham, F. (2016). Pengantar Manajemen Keuangan. Bandung: Alfabeta.

Jumingan. 2017. Analisi Laporan KeuanganJakartaPT Grasindo

Kasmir. (2015). Analisis Laporan Keuangan (cetakan ke delapan). Jakarta: Raja Grafindo Persada.

Meiliana, S., \& Nuryasman. (2020). Pengaruh Inflasi Kurs Dan Modal Kerja Terhadap Laba Perusahaan Perbankan. Jurnal Manajerial dan Kewirausahaan 2 , hlm 261-271.

Narafin, M. (2013). Penganggaran Perusahaan. Jakarta: Salemba Empat.

Putri, A. A., \& Supadmi, N. L. (2016). Pengaruh Tingkat Hutang dan Kepemilikan Manajerial Terhadap Persistensi Laba Pada Perusahaan Manufaktur. e-Jurnal Akuntansi Universitas Udayana, 915-942.

Raharjo, B. (2016). Memahami Laporan Keuangan untuk Manajer non Keuangan. Yogyakarta: CV. Andi Offset.

Rialdy, N. (2017). Pengaruh Modal Kerja Dan Total Hutang Terhapap Laba Usaha Perusahaan Manufaktur Yang Terdaftar Di Bursa efek Indonesia Periode 2011-2015. Jurnal Ilmiah Kohesi , 1(1).

Sasongko, S. N. (2014). Pengaruh Modal Kerja dan Volume Penjualan Terhadap Laba Bersih.

Sugiyono. (2017). Metode Penelitian Kuantitatif, Kualitatif dan R\&D. Bandung: Alfabeta.

Susilawati, E., \& Mulyana, A. (2018). Pengaruh Penjualan dan Biaya Operasional terhadap Laba Bersih PT. Indocement Tunggal Prakarsa (Persero) Tbk Periode 2010-2017. Jurnal Saintifik Manajemen dan Akuntansi, 74-87.

Zahara, A., \& Zannati, R. (2018). Pengaruh Total Hutang,Modal Kerja Dan Penjualan Terhadap Laba Bersih Pada Perusahaan Sub Sektor Batu Bara Terdaftar Di BEI. Jurnal Riset Manajemen Dan Bisnis (JRMB) , 3(2), 155- 164.

Zulia, H. (2009). Pengaruh Hutang Terhadap Laba Usaha Pada Pusat Penelitian Karet. Jurnal Ilmiah Kultura ISSN: 1411-0229. 